\title{
SOCIOPOLITICAL MESSAGES IN EASTERN ORTHODOX CHURCH BUILDINGS OF THE ERA OF ALEXANDER II IN PÄRNU COUNTY
}

\section{INTRODUCTION}

In Estonian historiography the topic of Orthodoxy has customarily been treated with caution and invariably in connection to the Russian Empire and the Russification policy, rather than the local Estonian Orthodox Christians. Yet a number of Orthodox churches in Estonia have been constructed purely for Estonian believers even before the political Russification started. Nevertheless, the political and social aspects cannot be left aside because these churches too contain a political message, but it differs in many aspects from the later historical attributions to it.

There is a noticeable rise in Orthodox church construction in Estonia from 1860s onwards and all the way through 1870s, occurring for the most part in regions where extensive religious conversion had taken place in 1840s. One such area is the historic Pärnu county, a place where fifteen new churches are built between 1864-1879 for the local Orthodox peasants. These churches carry a number of messages that on the one hand have undoubtedly been evaluated at the top level in the Holy Synod, but on the other, also reflect local conditions - political and social relationships within the community. 
The historical situation is first and foremost marked by iconostases and saint patronages that carry a broad set of social and political markers of the time when parishes were established and churches built. Every saint has a theologically and historically acquired meaning. Once it is combined with other saints on the iconostasis and then situated within the time of completion of the building and the iconostasis, it becomes a coherent message. Likewise, the artistic execution of churches and iconostases can be observed intentionally: as an expression of one's ideas.

Unfortunately, many churches built in Pärnu county over the observed period are destroyed by now and many more no longer retain their original iconostases; this article therefore only studies the surviving objects.

\section{PROLOGUE}

The abolition of serfdom brought Livonian peasantry legal freedom in 1819 but peasants soon faced a situation more difficult than they had before. Now they were tenants feeling the arbitrary hand of their lordly land owners. The new situation created unrest among the peasant population and culminated with several uprisings in mid-century - a great source of concern for local and imperial government in the light of events that had taken place in Europe between 1847-1848.

However, violence was not the only means to oppose the current regime. In parallel with the disturbances and with the help of several coincidences, a process known as "conversion movement" evolved: mass religious conversion took place among Livonian peasants. They abandoned Lutheran Church for the Orthodox denomination and - crucially - the institution of the Orthodox Church, the official church of Russia. The movement was volatile to the degree that some regions saw more than half of its population converting to Orthodoxy.

The conversion movement of 1840s took mostly place in village communities and this factor alone stood as an independent and cogent social argument - the nineteenth century village was still dominated by two important powers. First power was the local manor and its lord whose whimsy could still have a major impact on village life and destiny of particular people. The other important influence, conditionally qualified as a power, was local parish church and its pastor. Lords and pastors were both of German descent with rare exceptions - also, lord's support 
affected the course of appointment and lords would doubtlessly oppose pastors who do not meet their expectations. Last but not least, we must consider the fact that lords were also members of Lutheran congregations. At church services, peasants were constantly reminded of their lowly status because best seats were customarily reserved for the manor folk. In view of all of the above, we can reason that Orthodox church not only offered hope for economic gains but it also gave the repressed stratum of the society voice to express its dissatisfaction with the social reality.

Emperor Nicolas I era (1825-1855) minister of education Sergey Uvarov formulated a self-styled trinity of orthodoxy, autocracy, and nationality; this simple but striking idea expressed the official goal of ecclesiastical and cultural policies of the time - to equalize social conditions within the empire. It is important to note that Uvarov's system did not acknowledge the constraints stemming from nationalities. Instead was founded on faith, proficiency in the official Russian language, and estate within the society. While the regulatory side of reforms that tried to homogenise the country left peasants by and large untouched, the social dimension was tangible for them, increasing and sustaining their interest in Orthodoxy. The spread of Orthodoxy was subserved by the opening of seminary in Riga, the capital city of Livonia, in 1847. This was an extraordinary scholarly institution because unlike Russian clerical schools that admitted only children of clergymen, Riga seminary also accepted Latvian and Estonian peasants. ${ }^{1}$ This motion aided a major purpose - it was expected that the alumni of the seminary became local Orthodox clergymen and intellectuals, integrating the Empire and society more tightly with the help of Orthodoxy. Hence religious conversion enabled converts to achieve higher socioeconomic status and fulfil one's potential not necessarily through land settlements but also with the help of education.

It is a common view of the conversion movement that it took place mostly in poor areas and converts were peasants in meagre conditions. Whatever the case, in the context of Pärnu county one can only partly agree with this assertion. It is a point of fact that scores of converts lived

1 For instance, notable Estonian statesmen Jaan Poska and Konstantin Päts were both from Orthodox families and both studied at the cleric seminary in Riga. Considering their undisputable importance in building Estonian nationhood, we can tentatively say that the seminary succeeded in shaping the national intellectual elite. These examples also show that the Orthodox denomination did not guarantee loyalty to Russian Empire and its rulers. 
in economically backward coastal areas. A colloquial backward part of the county - Rannamaa - comprised of Audru, Tõstamaa, and Häädemeeste parishes. Remarkably, in the latter two parishes - Häädemeeste and Tõstamaa - close to eighty percent of the population converted to Orthodoxy between 1846 and 1848, while in Audru forty-six percent did. Extensive religious conversion also took place in Pärnu-Jaagupi parish, there one fourth of the people converted to Orthodoxy. Pärnu-Jaagupi was situated in yet another colloquial backward area - Korbemaa - a region in Pärnu county that over the course of the nineteenth century fell sharply behind in agriculture compared to the rest of the county. ${ }^{2}$ However, in Mihkli - a parish located in poor Korbemaa - there were few converts, which of course does not mean that there were none.

Extensive religious conversions in Rannamaa and Korbemaa seem to confirm the claim that religious converts came from economically backward regions, yet broad conversion also took place in Karksi parish - a place that historically belonged to Sakalamaa area $^{3}$ and was economically the most successful region in Pärnu county of its day. The parish landscape was dominated by large and prosperous farms, but this also resulted in a steeper social stratification - for instance in Sakalamaa, labourers rarely ate at the table of their tenant hosts. ${ }^{4}$ Possibly due to their greater economic freedom as early as in 1860s, a class of educated Estonians emerged in Karksi parish among Estonian Orthodox believers; they were interested in schooling their children at the seminary in Riga. ${ }^{5}$

Concerning the converts' social standing in the village society, it is frequently observed that early conversions took mainly place among cottagers and labourers, while later converts also included peasant tenants. ${ }^{6}$ It is quite problematic to take a final position in this case but we must consider the fact that as important a decision as change of faith might have demanded an authority figure whose example to follow. We know

2 Pärnumaa: maateaduslik, tulunduslik ja ajalooline kirjeldus, ed. A. Tammekann (Tartu: Eesti Kirjanduse Selts, 1930), 388, 434; Merike Ivask, Pärnu sillakohtu arhivaalid ajalooallikana 1866-1888, MA dissertation at the University of Tartu (Tartu, 2000), 40-41.

3 Halliste and Karksi parish areas, although historically part of Pärnu county, are in current administrative arrangement attached to Viljandi county.

4 Ivask, Pärnu sillakohtu arhivaalid ajalooallikana 1866-1888, 42.

5 On the regional differences in conversion movement, see Linda Lainvoo, Pärnumaa õigeusu kirikute ikonostaasid 1860. ja 1870. aastatel, MA dissertation at the Tallinn University (Tallinn, 2011), 39-44. On the topic of Orthodox clergy and converts in Southern Estonia, see Urmas Klaas, Õigeusu kirik Lõuna-Eestis 1848-1917: halduskorraldus ja preesterkond, MA thesis at the University of Tartu (Tartu, 1998).

6 Pärnumaa: maateaduslik, tulunduslik ja ajalooline kirjeldus, 214-215. 
for instance that in Jõõpre village of the Audru parish, the first convert was a local school clerk Jüri (Georgi) Krauverk and he was believed to have agitated conversion among locals. ${ }^{7}$ Thus in this case we may say that a school clerk was the local authority figure whose recommendations were followed. The fact that Krauverk was a school clerk adds a new dimension to the concept of religious conversion - namely, parish school clerk was the "salt of the earth" in the nineteenth century context, he was the one to bring erudition and consciousness about nationality into his locality and to fellow people. If a school clerk, a person educated and well informed of his community and time, decided to convert, then it follows that converts did not necessarily take place because of hearsay nor was religious conversion necessarily an abandonment of one's country and nation.

The first converts in Surju parish (later Häädemeeste) provide another case of this kind. Evidently, one of the first converts there was a wealthy and literate tenant Jaak Raab. A role model for villagers, he encouraged others to convert and infuriated a local lord. Besides Raab, also other convert tenants were known and they too had diverse issues with local nobility because of the conversion. ${ }^{8}$

Within the conversion movement, one must also consider purely pragmatic and geographic aspects - parish areas had traditionally been divided between churches until the situation changed in mid-nineteenth century. For many villages, this meant that parish church had been situated exceedingly far from home, so Orthodox parishes enabled the villagers to participate in religious proceedings much closer to home.

Although conversion rate varies regionally, it has been estimated that in total, 25-30 percent of Estonians in Pärnu County changed their denomination between $1845-1848^{9}$ and by mid-nineteenth century the share of Orthodox believers had become sufficiently large to be a considerable religious and social group, functioning alongside the Lutheran community, a shift that undoubtedly affected both sides.

7 Estonian Historical Archives [Ajalooarhiiv, EAA], 1921.1.217, 1-2.

8 Vladimir Berens, “Tahkuranna kirik”, Usk ja Elu, 1 (1993), 44.

9 Pärnumaa: maateaduslik, tulunduslik ja ajalooline kirjeldus, 214-215. 


\section{CHURCH AS A LANDMARK}

The construction of Orthodox churches and their placement was in most cases characterised by careful reasoned thinking as it had a goal to signal the presence of Orthodoxy to the local population - be it peasants, lords of manors or pastors - but also to travellers passing by. It is important to note that in construction, both widely used stock designs as well as original projects were used. The choice of the architectural design on the one hand indicated the taste of its day and the particular financial necessities, but on the other it made a public statement with the functional and aesthetic details of its construction.

Already in 1866, only one year after the first wooden church was completed at Seliste, both Kalli Church of St John the Forerunner in Mihkli parish and Uduvere James Zebedee Church in Pärnu-Jaagupi parish were finished using stock site plans by architect A. Edelson and both were consecrated within a week in November 1866. Kalli church was noteworthy because it remained the only Orthodox church in its parish due to the low religious conversion rate. The church building that is now almost completely destroyed, was built on the grounds received from the Kalli state manor. ${ }^{10}$ The church was located in a significant location, just next to the Haapsalu-Pärnu road, one of the most important connections in the area at the time. Apparently this was the reason for the choice of the location at the Kalli state manor, although there were two more state manors ${ }^{11}$ - Koonga and Võrungi, both located in the middle of much more densely populated areas which would have offered more comfortable locations for the church than the sparsely populated Kalli between swamps and bogs. On the face of it, the selection of place was a conscious and intentional effort, an opportunity used to exhibit the presence of Orthodoxy to the passing travellers on the HaapsaluPärnu road.

Contrary to Mihkli, the conversion movement in Jaagupi parish was lively so the construction of Orthodox church there was better motivated than in Kalli. Along the side of Pärnu-Jaagupi, an Orthodox church was

10 Urmas Viilma, Egle Tamm, Churches of Pärnu County (Pärnu: Pärnu Maavalitsus, 2001), 28.

11 Most of the Orthodox churches built in Pärnu county during the observed period were located on the state manor grounds, because lords of manors were mostly of Baltic-German nobility, who were generally not interested in the spread of Orthodoxy among the peasants of their manors and therefore it was impossible to build Orthodox churches on their grounds. For details, see Lainvoo, Pärnumaa kirikute ikonostaasid, 21-22; 48-57. 
built in Uduvere and because of its location it was dedicated to apostle James, son of Zebedee. The construction was mostly funded by the Holy Synod, but also by local people and other parishes. ${ }^{12}$ Here too the location of the church seemed to honour the wish to make the presence of Orthodoxy noticeable. The Orthodox church is less than two kilometres apart from the local Lutheran church, hence in this case it cannot be claimed that the choice of location made visits from more distant villages of the parish significantly easier. Once again the decisive aspect of the choice seemed to be closeness of an important passing road. Namely, Tallinn-Pärnu road passes the church in one and half kilometre distance. The reason why church was not built on the roadside can be explained by the fact that in Jaagupi parish, the road crossed territories of knight manors and the construction of an Orthodox church on these grounds would have been complicated without the agreement of the lords whereas the Uduvere manor was a constituent manor of the Enge state manor and thus it was much easier to raise an Orthodox church there. It seems that true interests of the Orthodox Christians in Jaagupi parish were served twelve years later when Kergu Orthodox church was built seventeen kilometres from Uduvere in the north-east corner of the parish. This event will be discussed in detail below.

Only two years later in 1868-1869, construction of two Orthodox churches finished once again, and again in locations that witnessed minor religious conversion in comparison to other parishes in Pärnu county. In 1868, Tori Nativity Orthodox Church was finished. As the conversion to Orthodoxy was modest in Tori parish, it seems that this church - built on the grounds of a state manor, situated by a major road route, and only two kilometres from Lutheran church, also reveals a wish to establish an Orthodox landmark and the aim to serve the needs of Orthodox community appears to have been less important.

In February 1869, soon after the construction of the church in Tori was completed, Sts Apostles Peter and Paul Orthodox Church was completed in Vändra, again by architect A. Edelson's stock site plan. ${ }^{13}$ The Orthodox church in Vändra too was situated in a remarkable place - the most important connecting roads cross the front of the church. It was impossible to travel from Pärnu to Türi, Paide, Rakvere,

12 Viilma, Tamm, Churches of Pärnu County, 30.

13 As the church was rebuilt during the Soviet period only original outer walls survived. 
or Suure-Jaani and Viljandi, without taking notice of Sts Apostles Peter and Paul Orthodox Church. The location of the church on the Uue-Vändra manor grounds is somewhat surprising, but when we consider the extremely close relationship between the lords of the manor, von Ditmars, and the Russian nobility close to the emperor ${ }^{14}$ then the whats and hows of the Orthodox church construction in an area of a small Orthodox community - moreover - on the grounds of a knight manor, become clear.

Similarly to other coastal parishes Tõstamaa and Audru, Häädemeeste also had a high number of Lutheran Orthodoxy converts at around eighty percent of the population. A large number of the converts in Häädemeeste parish were successful in obtaining land settlements that they had hoped for - in the southern parts of the parish, Rannametsa village was established for this purpose on the Tahkuranna state manor grounds as well as Krundiküla village on the Häädemeeste state manor grounds. Until 1862, Häädemeeste had been a coastal area within Saarde parish, but to deal with the consequences of the religious conversion and to strengthen the position of Lutheran church, Häädemeeste church parish was established in $1862 .{ }^{15}$ Häädemeeste and its vicinity witnessed an era of tremendously rapid church construction between the years 1870 and 1880: four churches were scattered onto a twenty kilometre roadside section of the Old Riga Road, two of the churches are Orthodox and two Lutheran.

In 1849, the first Orthodox community was established in the Häädemeeste area and soon afterwards planning of the construction of church started. Still it took almost twenty five years until the building was completed and the Church of the Transfiguration of Our Lord at Häädemeeste was consecrated in 1872. As was common at the time, the construction of Häädemeeste church was funded by the Holy Synod. ${ }^{16}$

\footnotetext{
14 Lord of the Vändra manor, Woldemar Adolph von Ditmar died in 1837, having served in the Imperial Russian Army in the rank of major. In 1844, the manor was divided in two between his sons Woldemar Friedrich Karl von Ditmar and Friedrich Ferdinand Gustav von Ditmar. Vana-Vändra manor was left to Woldemar Friedrich and Uue-Vändra manor to Friedrich Ferdinand. Both lords and their families had close ties with the Russian nobility and the court. Friedrich Ferdinand served in the Imperial Russian Army in the rank of major general, earning the Order of St George IV Class and was married to Tatyana Shulgina, the daughter of lieutenant general Dmitry Shulgin. Carl, the son of Woldemar Friedrich, was a well known Russian geologist, whose greatest work is the study of Kamchatka peninsula.

15 Viilma, Tamm, Pärnumaa kirikud, 4.

16 Urmas Sinkel, “Õigeusu kirikuid Pärnumaal”, Usk ja Elu, 1 (1998), 8.
} 
Häädemeeste had very active community because it wais noted as late as in 1935 that in spite of the low construction quality needing continuous attention and regular repairs, and questionable choice of church location, the congregation had provided all means for the repair and maintenance work from its inception. ${ }^{17}$ It is in order to point out that the ability to keep the church building in good order throughout its existence indicates that for the congregation members, church was sufficiently important and significant to keep it in good condition; even today there is a functioning congregation and the building is in good condition.

The building of the Mihkli (St Michaels') Lutheran church about one kilometre from the Orthodox church in Häädemeeste begun only a year after the consecration of the Orthodox church in 1873, and construction work was finished in one year, by 1874 . The church was built with the support of the baron of Uulu Reinhold Stael von Holsten, ${ }^{18}$ who had unmistakably set his heart on the advancement of the Lutheran church in the coastal region. In addition to supporting the construction of the Lutheran church in Häädemeeste, von Holsten backed church construction in Uulu, a place few kilometres outside of the Häädemeeste parish in the direction of Pärnu - a Lutheran church was built there in 1880; and lastly, with his support a church was built in Tahkuranna in 1891. The Orthodox and Lutheran Church construction on this scale points in all likelihood at the attempts by both Churches to enforce their position regardless of the expense so in addition to the immediate sacral function of the churches, they also served as competitive landmarks around the Riga road.

Also in $1872^{19}$, about twenty kilometres towards Pärnu from Häädemeeste Orthodox church, building work of the extraordinary Tahkuranna Dormition of the Mother of God Orthodox Church was completed in Häädemeeste parish. The need for a new church was related to the fact that for a number of Orthodox believers in the congregation, Church of the Transfiguration of Our Lord at Häädemeeste was too far and the church could not be visited often enough. The construction was initiated by the Orthodox Brotherhood in Kronstadt and for the purpose of carrying out the work, an Orthodox Brotherhood in Tahkuranna was congregated and given the Tahkuranna manor, the income from its

17 Pärnumaa ap.- õigeusu praostkonna album (Pärnu: Oma, 1935), 10.

18 Viilma, Tamm, Pärnumaa kirikud, 37.

19 Alternatively, 1871 by some accounts. 
estate was used for the church construction. ${ }^{20}$ To cover the substantial building expenses of thirty-seven thousand rubles in total, the congregation received contributions also from Kronstadt and Saint Petersburg. ${ }^{21}$

The author of the church project, Grigory Karpov, ${ }^{22}$ was also a member of the local Orthodox Brotherhood and both the church architecture and its interiors manifested in many ways an intense Romantic longing for a Russia of the past - a feature that characterised Orthodox Brotherhoods in general. Tahkuranna church, an architectural mirror image of a secularly pious attitude, exemplified in many aspects a different language of form from places of worship funded by the Holy Synod.

\section{ENCODED MESSAGES ON THE ICONOSTASES}

\section{HÄÄDEMEESTE}

In the previous section we covered churches as geographic landmarks and devices of communication as looked at from the outside. It is now productive to also examine church interiors and messages transmitted to those who enter through their doors.

The largest iconostasis in Pärnu county may be found in the Church of the Transfiguration of Our Lord in Häädemeeste, completed in 1872. The iconostasis is a richly decorated wall of icons realized in eclectic style with prominently exhibited Neoclassic elements. Most of the original icons on the church iconostasis have survived. The icons on the iconostasis unmistakably stem from the Western painting tradition and are therefore quite common both in their context of nineteenth century Russian Orthodox tradition as well as in their dependence on the artworks in Western tradition. In this stead, the Madonna of Häädemeeste iconostasis is plainly based on Raphael's Sistine Madonna and the likeness is so detailed that it follows the overall composition of the figures as well as colours and poses. The icon of Christ Pantocrator in ancient clothing matches Madonna in its execution, composition, and colour rendering but Christ is in many ways derived from models of the Italian Renaissance. In a similar manner, the icons of arch angels Gabriel and Michael harmonise with the icons of Christ Pantocrator and Madonna,

20 Viilma, Tamm, Pärnumaa kirikud, 22.

21 Pärnumaa ap.-õigeusu praostkonna album, 33.

22 Viima, Tamm, Pärnumaa kirikud, 22-23. 


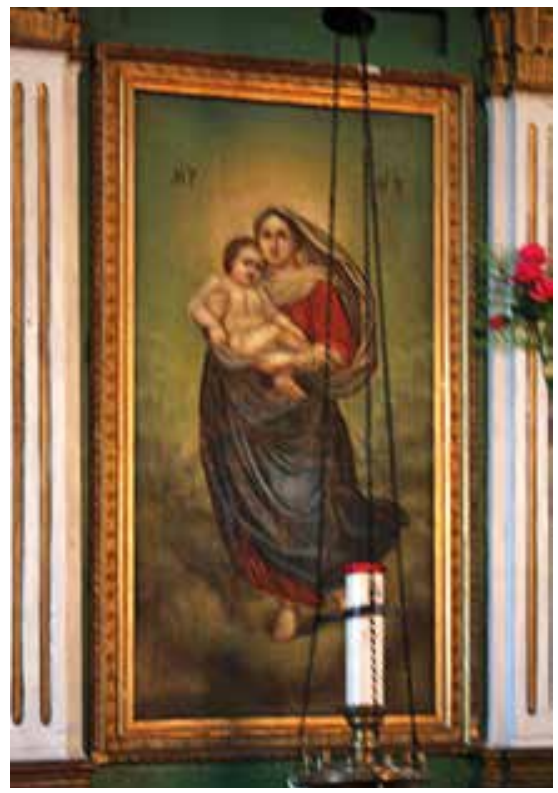

Fig. 1. Häädemeeste, Mary with Child: Holy mother with the child from the iconostasis at the Church of the Transfiguration of Our Lord in Häädemeeste; a copy of Raphael's Sistine Madonna (early 1870s). Photo by Linda Lainvoo

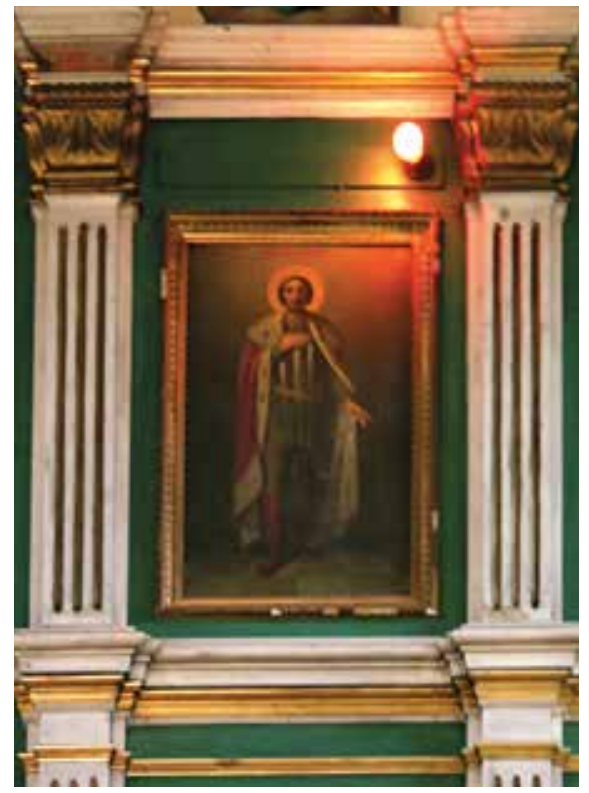

Fig. 2. Häädemeeste, St Alexander Nevsky: St Alexander Nevsky from the iconostasis at the Church of the Transfiguration of Our Lord in Häädemeeste (early 1870s). Photo by Linda Lainvoo

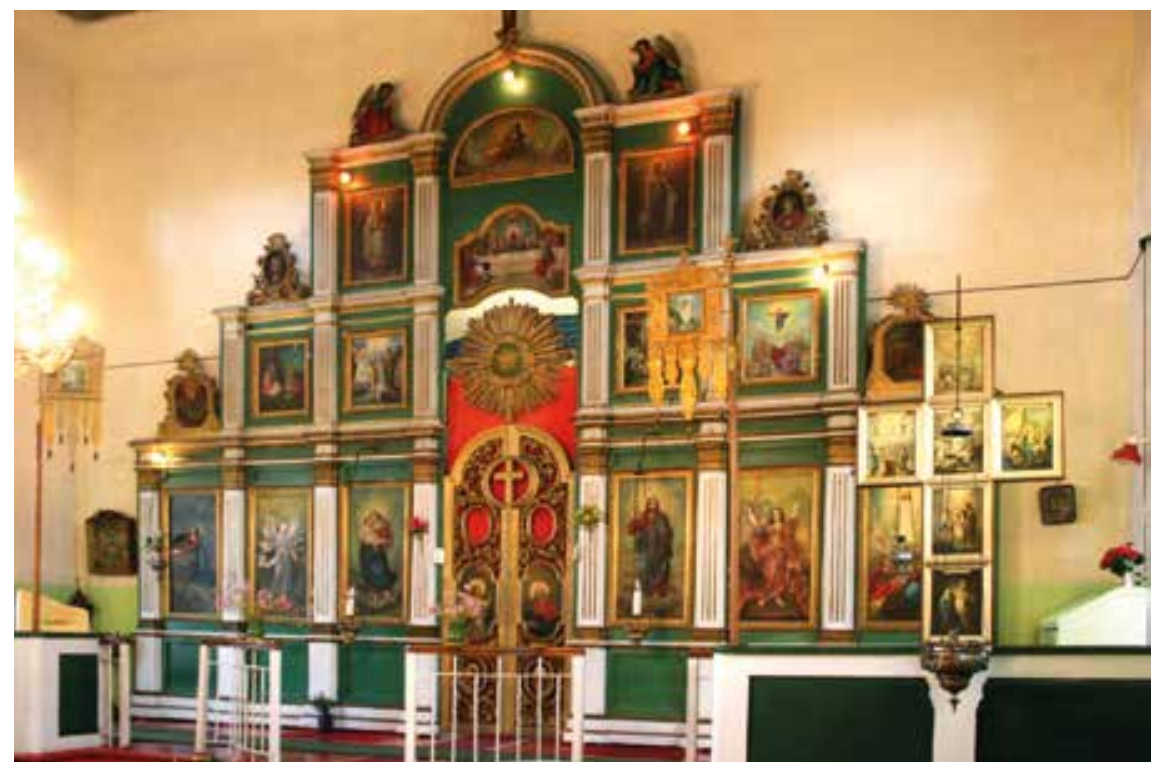

Fig. 3. Häädemeeste: The iconostasis at the Church of the Transfiguration of Our Lord in Häädemeeste (early 1870s). Photo by Linda Lainvoo 
yet Classicist painting tradition is more felt in the depiction of arch angels where the Renaissance stylistic elements are pushed further to the background.

The icons portraying Biblical events are grounded in a simple style of expression, adhering to the central perspective and uniting elements from Renaissance, Mannerism, Baroque, and Classicism; in this way paintings become clearly defined and easily comprehensible. So in Transfiguration influences of the Late Renaissance and Mannerism are seen, bearing some similarity to Paolo Veronese's Transfiguration of Christ, yet remaining inferior to it in vigour and in the number of details. Then again, the composition of Last Supper is clearly based on horizontal construction around long table, widely used in Italian Renaissance.

The icon style of Saint Nicholas and Saint Alexander Nevsky is based in large part on the Classicist painting tradition: full length figures are carefully and precisely painted, have a dignified stature and ceremonially glance at the members of the congregation from a height. In contrast to the other icons, the halos of these two saints are represented differently - while the rest of the paintings on the iconostasis depict halos as light-coloured diffused radiation, Saint Nicholas dressed in bishop's vestments and Saint Alexander in a purple fur-trimmed sovereign coat, have clearly outlined golden halos, pointing clearly towards the Orthodox painting tradition, in contrast to the Classicist realism of the icon paintings of the iconostasis.

There are several ways to explain for the striking size of the building of the Häädemeeste Church of the Transfiguration of Our Lord as well as for it containing such an imposing, large iconostasis. To begin with, it is certainly important to take record of the fact that there was a large number of Orthodox Christians in the Häädemeeste area after the religious conversion of 1840s. Over the two decades following the establishment of the local Orthodox congregation, it had several ethnic Russian priests but in regards to construction of the church, the most important among the priests was the ethnic Estonian Kalinik Prants, who served in Häädemeeste from 1867 onwards. ${ }^{23}$ The struggle between two congregations and two denominations that commenced in 1862 when a Lutheran parish was established in Häädemeeste to strengthen

23 Tõnis Joarand, "Häädemeeste Issandamuutmise Apostliku Õigeusu Kirik - 120 aastat", Usk ja Elu, 1 (1993), 32. 
the position of Lutheran Church and to prepare for the construction of its new church building, is evident on the iconostasis of Häädemeeste Church of the Transfiguration.

The Häädemeeste iconostasis is in addition to its sheer size also one of the artistically most remarkable icon screens of the era - expressed both in the icon work and in the realisation of the screen itself. Although the height and width of the iconostasis would have rendered possible a canonical tier structure, completely different approach is chosen: numerous colourful depictions of Great Feasts are placed on the iconostasis, depiction of the saints avoids prudishness and outstanding examples of Western art are used as models. The iconostasis demonstrates that Orthodox congregations spared no effort to prove the value of Orthodoxy to the Lutheran community, showing that an Orthodox church is not inferior to a Lutheran church in any aspect of its aesthetic intentions or artistic realisation.

Besides the Great Feasts, saints are depicted - St Nicholas and St Alexander Nevsky. It is instructive to examine the latter in depth: to understand the significance of Alexander Nevsky as a saint, we must start by revising his life history and also history of Alexander the saint. Alexander Nevsky was a prince of Novgorod who lived in mid-thirteenth century. During his lifetime, Tatars attacked Russian lands from the south east while Swedes, Lithuanians, and Teutonic Order assaulted from the west. In 1240, Alexander defeated Swedes in a battle on the shore of Neva River and for this he was awarded the agnomen Nevsky; in 1242 he achieved victory over the knights of the Teutonic Order in the Battle of Lake Peipus. It was believed that Alexander was pious in character and he was inspired by revelations of Boris and Gleb. Alexander was canonised in 1381 by Cyprian, Metropolitan of Kiev and All Russia. The rising of Alexander Nevsky into imperial favour and being canonised coincides with Dmitry Donskoy securing victory over Tatars. Dmitry saw that by dignifying his forebear, he could strengthen his own political prestige and power. ${ }^{24}$ The importance of Alexander among other saintly princes grew over time and Peter I had his remains transferred from Vladimir to Saint Petersburg and made him the patron of the new Russian capital city. ${ }^{25}$ In the context of nineteenth century and the establishment of church at

24 David Farmer, The Oxford Dictionary of Saints (Oxford: Oxford University Press, 2004), 15.

25 Georgij Fedotov, Svjatye drevnej Rusi (Rostov-on-Don: Feniks, 1999), 112-113. 
Häädemeeste, it might be worth noting that the emperor at that time was also named Alexander. ${ }^{26}$ Alexander Nevsky was considered to be one of the most important saints in the context of imperial Russia. ${ }^{27}$ On the one hand, Alexander expressed the unity and wholeness of Russia, on the other, the confrontation with Western forces - Swedes as well as Germans. The latter aspect is especially important in the context of Häädemeeste church construction.

Also noteworthy is the way in which Alexander Nevsky is depicted at Häädemeeste. The icons of Alexander could employ several different approaches in parallel - he could be represented as a meek, pious monastic servant but also as a warrior and sovereign. ${ }^{28}$ Obviously different icon types carry different messages. The fact that Alexander is depicted as a glorious and majestic sovereign on the Häädemeeste iconostasis, points at the intention to stress his political significance and grandness.

Hence the iconostasis at the Häädemeeste Church of the Transfiguration of Our Lord reflected in many ways the struggle and desire to show the triumph of the Orthodoxy, its intellectual and artistic standing, but also to show the presence and power of the Russian Empire that in past had been capable of defeating the Germans and forcing them to withdraw. It is quite certain that comparison with Lutheran church was kept in mind while building the Orthodox church and therefore much effort was put into the appearance because it was not known how the new Lutheran place of worship and its interiors would exactly look. So every measure was taken not to fall behind the Lutherans.

\section{TAHKURANNA}

Although the construction of Häädemeeste Church of the Transfiguration of Our Lord and the nearby church - Tahkuranna Dormition of the Mother of God Church - were finished at the same time, the latter building represents an altogether different taste both in its construction and style of iconostasis.

26 The growth of Alexander's importance during the nineteenth century is also evident in the fact that over the century, as many as three Russian emperors bore the name Alexander.

27 Oleg Tarasov, Icon and devotion: sacred spaces in imperial Russia (London: Reaktion Books, 2002), 294.

28 Gleb Markelov, Svjatye Drevnej Rusi: materialy po ikonografii, t. 1: Svjatye Drevnej Rusi v prorisjah i perevodah s ikon XV-XIX vekov: atlas izobraženij (Saint Petersburg: Dmitrij Bulanin, 1998), 52-55. 


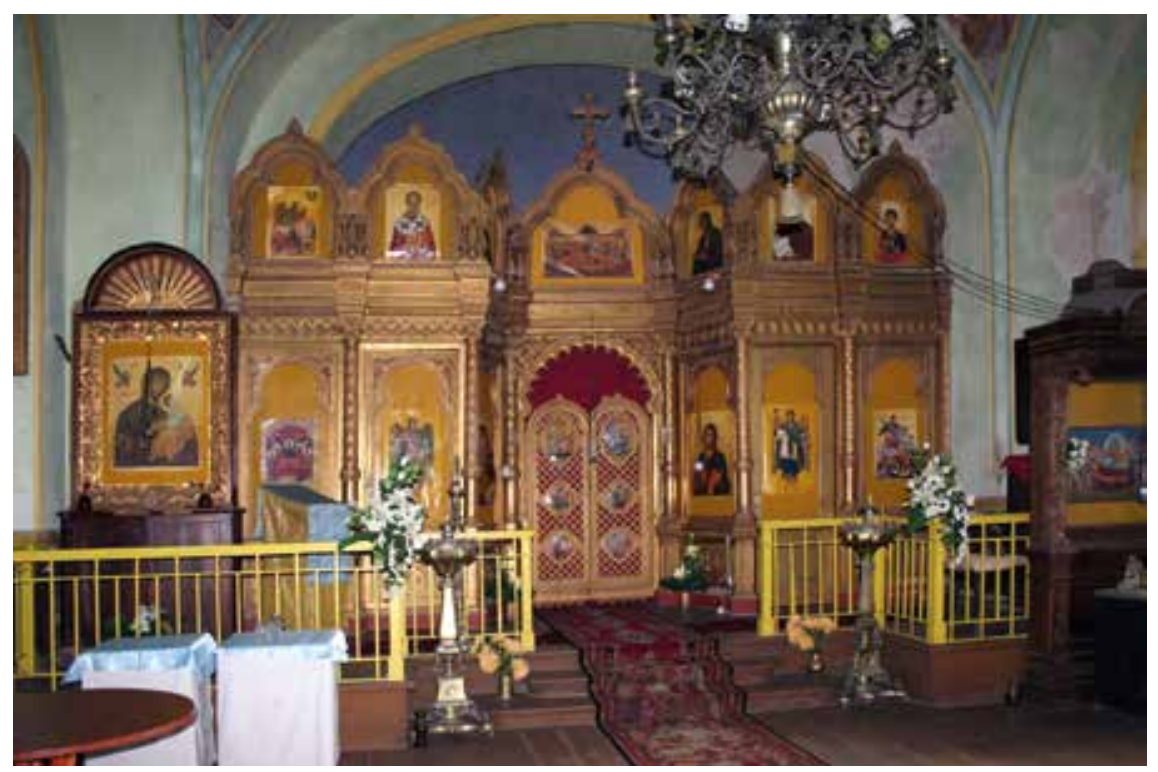

Fig. 4. Tahkuranna: The iconostasis at the Tahkuranna Dormition of the Mother of God Church (early 1870s, G. I. Karpov's project). The icons on the iconostasis have been stolen between the late 1980s and early 1990s. At present, posters of icons are placed on the iconostasis. Photo by Linda Lainvoo

The Tahkuranna church interior is darker and mystical, lacking the serenity and Neoclassicism of the Häädemeeste chuch. The wholly gilded two tier iconostasis is made after the drawings by architect Grigory Karpov; ${ }^{29}$ the iconostasis is also historicist in style but revives romanticised Old Russian art and makes little import of the European examples. The first tier of the iconostasis rests on a panelled parapet that is fitted on the socle. Icons with a trefoil top side are now lost but they were structured with two part carved columns. A zigzag frieze finishes the first tier, supporting in turn the horizontal section with several interlaced motifs. The icons in the second tier of the iconostasis are also placed in trefoil top icon enclosures, but joint with a double baluster instead.

The Royal Gates of the iconostasis recede from the surface plane, resulting in a situation where perpendicular viewpoint does not reveal part of the transennae, namely the two icons by the Royal Gates: Mother with the Child on the viewer's left and Christ Pantocrator on the viewer's right. The reverse ogee lintel is designed in the form of a golden

Berens, “Tahkuranna kirik", 47. 
lattice and onto it, icons in gold framing are attached. A billowy arch surrounded by complex ornamentation is situated on top of the Royal Gates. In the second tier on top of the Royal Gates, there is a crucifix.

The Tahkuranna iconostasis shows rich use of a number of different elements invoking the Old Russian style and originating from disparate periods and locations - from thirteenth century Novgorod to sixteenth century Moscow. The glorious and mythic look is extraordinary in the context of 1870s Pärnu county as such a clear influence of the Old Russian style becomes commonplace only during the final decade of the nineteenth and the beginning of the twentieth century.

In a period of few years spanning from the end of 1980s to the start of 1990s, almost all original icons were stolen from the church. ${ }^{30}$ Thus our perception of the depictions on the iconostasis is mediated by the photos taken before the thefts and pillages took place. ${ }^{31}$ On the basis of photos only, it is difficult to describe the icons in more detail but it is evident that more canonical approach was taken here than on the Häädemeeste iconostasis. This is most clearly seen in the usage of golden backdrop and also in rather flat style of painting. Unfortunately, the extant photos are taken perpendicularly at the front of the iconostasis and it is therefore impossible to see some works in the transennae group of the icons. However, one can say that the general stylistic approach, execution, and overall look of the iconostasis expressed a clear stylistic language of the Romantic Old Russian taste, evidently a novel and exceptional sight for the members of a congregation with Lutheran past.

The outcome of the Tahkuranna church construction owed much to the conditions and necessities of the era. Namely, as a young Estonian Nikolai Prants ${ }^{32}$ was appointed the priest of the parish in 1869, he requested a more suitable place of worship instead of the limited space in barracks used by the congregation at the time. To achieve his goal, he first tried to reach an agreement with the Tahkuranna manor tenant I.F. Gerstfeldt, but the tenant was hostile to the idea of renting rooms to an Orthodox congregation. In reply to father Nikolai's plead Gerstfeldt announced that he would rather let in a Jew than a Russian

30 Heljula Mengel, verbal message (5.11.2010).

31 From the photos following icons can be ascertained: Archangel Gabriel, Archangel Michael, Dormition of the Mother of God, Baptism and Transfiguration.

32 His brother Kalinik Prants had been appointed the priest of Häädemeeste parish two years ago. 
pope. ${ }^{33} \mathrm{~A}$ reaction of this kind quite probably expressed the Baltic German attitude towards converts and Orthodoxy in general - it was seen dangerous and imperialistic.

As the congregation was still in need of an appropriate place of worship, the young priest continued his attempts to find a way to build a stone church, using help from his influential friends and acquaintances. ${ }^{34}$ The newly established Orthodox Brotherhood in Kronstadt that counted a great number of its members among the nobility, wealthy bourgeois as well as military officers proved to be just the right kind of organisational support for church construction. The church was built by the endowment from the members of the Order ${ }^{35}$ and an Orthodox Brotherhood in Tahkuranna was called into being to coordinate the construction work locally. The overall cost of the work amounted to 37,000 rubles, ${ }^{36}$ and as already mentioned, funds came in form of gifts from Orthodox supporters in Kronstadt and Saint Petersburg. ${ }^{37}$ Considering the fact that the initiative to build the church as well as its funding originated from outside of the local parish and taking into account that Orthodox fraternities had a close relationship with slavophiles and shared the view popular in slavophile circles that Orthodox Church must be active and be more visible in the Baltic provinces - one can infer that the aesthetics of the church was at least to some degree also dictated by the Brotherhood. This explains the differences between Tahkuranna and other churches constructed in Pärnu county during the 1870s where Orthodox fraternities were not directly involved. ${ }^{38}$

\section{KERGU AND JÕÕPRE}

Two in many aspects similar Orthodox churches were completed in Pärnu county at the end of 1870s. Both the Kergu Orthodox Church of Grand Martyress Sinaida in Jaagupi parish and Jõõpre Orthodox Church of St Georgy the Great Martyr ${ }^{39}$ in Audru parish are worth a look. The churches

33 Berens, "Tahkuranna kirik", 45.

34 Ibid.

35 Sinkel, "Õigeusu kirikuid Pärnumaal”, 8.

36 Pärnumaa ap.-õigeusu praostkonna album, 10.

37 Viilma, Tamm, Pärnumaa kirikud, 22.

38 In 1872, the construction of the Orthodox Church of Saint Nicholas in Kilingi-Nõmme was completed; in 1873, Pootsi-Kõpu Holy Trinity Apostolic Orthodox Church and the Church of the Ascension of Our Lord in Uruste were completed.

39 The Slavic form is used here on purpose. 


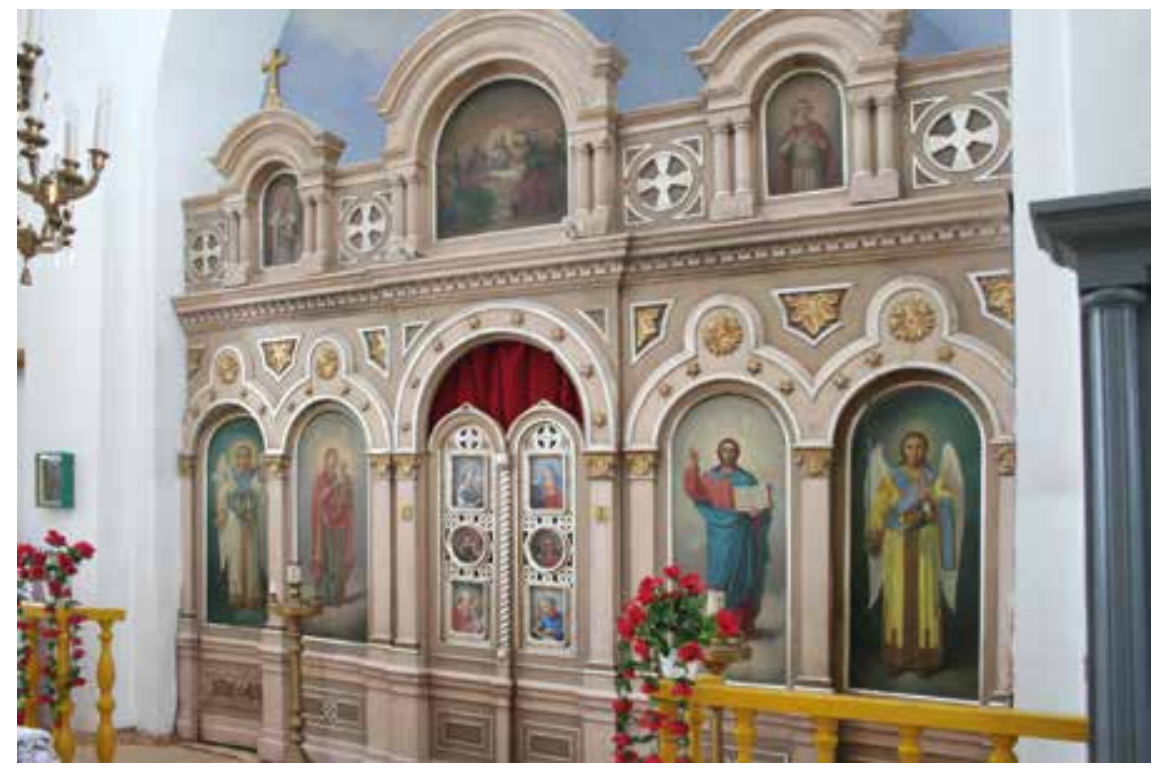

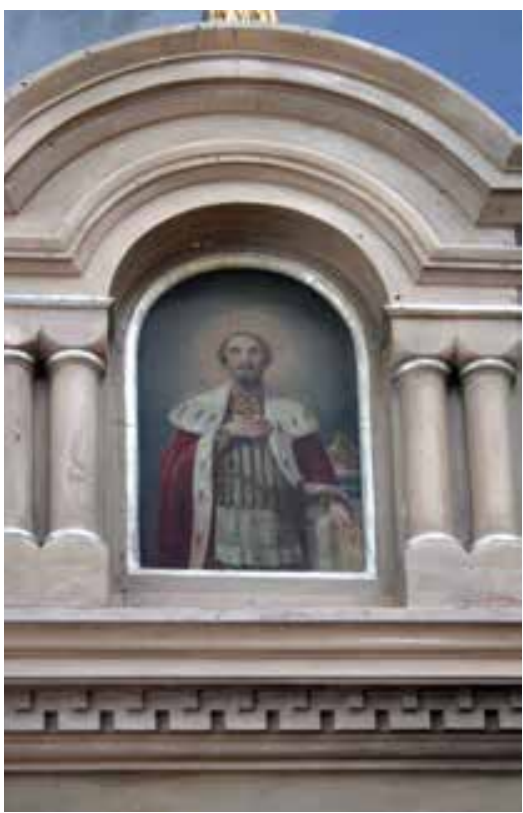

Fig. 6. Jõõpre, St Alexander Nevsky: St Alexander Nevsky on the iconostasis at the Jõõpre Orthodox Church of St Georgy (1870s). Photo by Linda Lainvoo
Fig. 5. Jõõpre: The iconostasis at the Jõõpre Orthodox Church of St Georgy (stock design, 1870s). Photo by Linda Lainvoo

were in both cases located in an area of active religious conversion and in a parish that already boasted an outstanding Orthodox church. Also, in Kergu and Jõõpre, the language of architectural form is similar.

In 1878, Kergu Orthodox Church of Grand Martyress Sinaida was completed, founded on the land received as a gift from the Kergu manor. The manor belonged to von Keyserling family and the initiative to endow land for the Orthodox church came from Sinaida, the wife of Alexander von Keyserling. ${ }^{40}$ By the project of architect Gardenack a small charming,

40 Viilma, Tamm, Pärnumaa kirikud, 39; Sinaida von Keyserling was the daughter of Russian Minister of Finance Georg von Cancrin. 


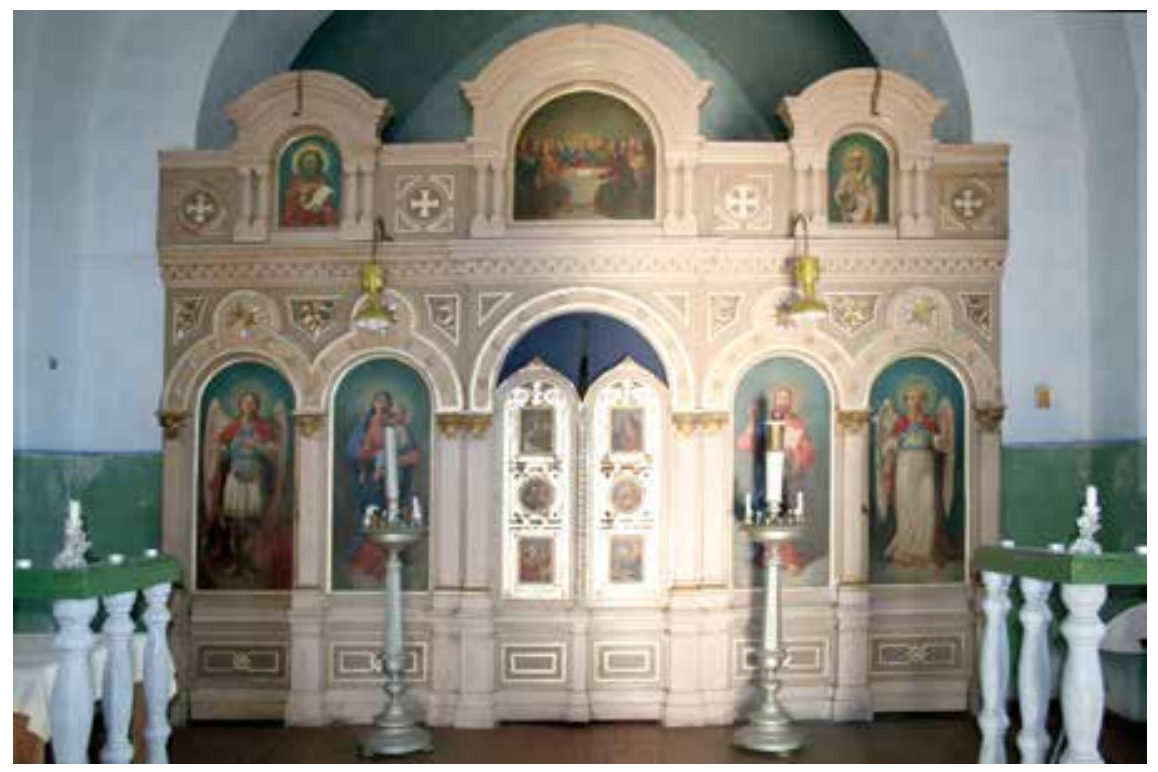

Fig. 7. Kergu Orthodox Church of Grand Martyress Sinaida (stock design, 1870s). Photo by Linda Lainvoo

historicist parish church was built that playfully contrasts granite stone and red brick. ${ }^{41}$ The church building has a square floor plan, a stubby bell tower topped by an onion dome and a low tambour also topped with an onion shaped dome; it is adorned with cornices and friezes giving it a romantic appearance reminiscent of a fairy tale.

Even though the church land was given by the lady of manor and therefore the church had some approval, the Kergu Orthodox congregation still had unending issues and frictions with the nobility and Lutheran pastors. As late as in 1935, complaints were still aired about the official maps: at times labels "Russian church" and "Russian cemetery" were used ${ }^{42}$ which the members of the congregation took as an obvious insult. This case indicates that everybody was not favourably minded towards the construction of local Orthodox churches.

The Jõõpre Orthodox Church of St Georgy the Great Martyr was completed in 1879. In many ways it is similar to the Kergu Church: the building exteriors also make use of cornices and friezes and it is built using a combination of granite stone and red bricks. The western entrance

41 Sinkel, “Õigeusu kirikuid Pärnumaal”, 11. Another spelling of the name is Gardenek. 42 Ibid. 
is dominated by a slender bell tower topped with an onion dome and above the crossing there is a tall tambour also with an onion dome and with large windows. It is known that the construction of the church was funded similarly to the other Audru parish Orthodox church in Uruste, by the Ministry of Internal Affairs, and the architect was named Fenk. ${ }^{43}$ The church has graceful proportions and seems therefore a bigger accomplishment than the Kergu church that had a certain roughness of proportions.

Evidently the Orthodox church at Jõõpre signalled the spreading of the denomination because it is precisely here where the accounts of Orthodox Christians' suffering and persecutions were well documented.

The iconostases of these two churches must also be comparatively studied. While the church buildings are different, their iconostases are in fact similar to the smallest detail. Both iconostases feature icon walls utilising light-colour background and gilded decorative details, dominated by elements of Renaissance and Classicism. Both iconostases are relatively small and two tiered in type, there are merely four icons in the first tier and in the second, only three. The first tier stands on a panelled socle. The round arched icons in the first tier are framed by simple quadrangular pilasters and finished in round arched, embellished decorative framing that encompasses the icons. The first tier is divided from the second by a simple frieze, on it rests the second row of icons, structured by modestly decorated panels and rounded double pilasters. The iconostases are finished with segmental arch framings placed above icons and on top of the framing there are simple golden Latin crosses.

Kergu $^{44}$ and Jõõpre ${ }^{45}$ iconostases are not only similar in the realisation of icon wall - the icons on the wall are also very much alike, confirming the fact that artworks came from the same workshop. In both cases, icons are soft-hued, somewhat naïvely painted works with distinctly outlined figures placed on delicate light backgrounds. Nevertheless, even if they are similar, the icons are not identical copies - for example in Jõõpre version, archangel Michael is depicted in liturgical vestments while at Kergu, Michael wears a Roman armour comparable to the suit

43 Viilma, Tamm, Pärnumaa kirikud, 40.

44 On iconostasis, there is Christ Pantocrator, Archangel Gabriel, Madonna and Child, Archangel Michael, Prophet Daniel, Saint Sinaida, Last Supper.

45 On iconostasis, there is Christ Pantocrator, Archangel Michael, Madonna and Child, Archangel Gabriel, Alexander Nevsky, Saint Georgy, Last Supper. 
of armour worn by Saint Georgy ${ }^{46}$ at Jõõpre. A curious anomaly emerges in the way archangels are represented on the iconostasis at Kergu. Namely the placement of archangels is swapped so that Michael is next to Madonna while Gabriel is set next to Christ Pantocrator. Here it is difficult to ascertain if the placement is original or a mistake has been made during a later disassembling and reassembling the iconostasis.

It is difficult to compare the icons of Madonna and Christ Pantocrator based on contemporary iconostases because in Jõõpre, the Madonna and Christ of the original composition were replaced in 1911 with new icons, donated by a member of the congregation, Tõnis Vaiman in memory of his deceased wife and daughter. ${ }^{47}$ Based on a surviving photo, one can ascertain that representations of Christ Pantocrator and Madonna in both Kergu and Jõõpre were of the same type and both were carried out in a similar manner. Additionally a register of Jõõpre church property from 1880 confirms that over time, there have been no changes made in icons on the iconostasis - i.e. the icons of Alexander Nevsky and Saint Georgy have both been part of the original composition of the iconostasis. ${ }^{48}$ The comparison with Kergu iconostasis allows one to better visualise the original icons of the transennae group in the Jõõpre iconostasis.

The depictions of prophet Daniel and Saint Sinaida on the Kergu church iconostasis reveal a kindred painting style and choice of colours to what is found on the icons of Alexander Nevsky and Saint Georgy at Jõõpre - in all cases there is a two thirds figure, covering the surface of the icon almost in full. The Last Supper is also depicted in a similar way - unlike other iconostases discussed so far, this mode of representation stands closest to the Flemish Baroque depictions of the Last Supper and is less similar to the examples of Italian Renaissance. However, the Kergu and Jõõpre Last Suppers are not without their differences. The poses of figures, the manner in which the figures are depicted, and their facial expressions match in large part, but for instance Judas Iscariot is placed in a different part of the composition. Analysing the iconostases at Kergu and Jõõpre, it stands to reason that the iconostases vary because conscious choices about variations have been made.

In spite of the same construction period and similar iconostases the two churches were built in remarkably different social environ-

46 The Slavic form of the name is used on purpose.

47 EAA.1291.1.217.

48 EAA.1921.1.210, 3-4 
ments. Hence it can be reasoned that different settings were reflected in the choice of saint patron as well as in the icons that were used. Kergu Orthodox congregation was held in favour by the lord of the manor from its inception in 1852 as the initial place of worship was a rented room at the manor. In 1862, the lady of the manor Sinaida von Keyserling bestowed 1220 square fathoms of land on the congregation to erect a church. The congregation dedicated the church to the Great Martyr Saint Sinaida in recognition of the endowment. ${ }^{49}$ The formation of Jõõpre congregation and construction of the church building backlashed because of the strong resistance of the Baltic German manor tenant P. Frei. ${ }^{50}$ His conflict witch Jüri (Georgi) Krauverk is documented in the church chronicles. When the school clerk converted to Orthodoxy and then incited a religious conversion among locals, manor tenant Frei allegedly organised his persecution and imprisonment for several years. ${ }^{51}$

We can speculate that it is by virtue of the social environment and alliances with the lords in position of power, that Kergu and Jõõpre church iconostases, although identical in form, are completely different in content. Although issues with lords and the Lutheran Church appeared later in Kergu and carried over to the strained relations with the local Lutheran population, ${ }^{52}$ the formation of Orthodox congregation and the construction of the church was entirely peaceful in terms of power relations and as a result, the icons on the iconostasis are much less belligerent. In contrast, the situation of the first Orthodox believers in Jõõpre was rather complicated and the iconostasis features as many as two warrior saints - Alexander Nevsky and Saint Georgy - both embodying bellicosity and rebellion. Alexander Nevsky and the significance of his figure was discussed above, but in case of Jõõpre church, a closer look at its patron saint is also worthwhile. Saint Georgy, known in Estonian as Püha Jüri, is a Christian saint that lived between the end of the third century and the beginning of the fourth century and was active in the Palestinian region. Saint Georgy is frequently depicted as a warrior holding a spear or a

\footnotetext{
49 Pärnumaa ap.-õigeusu praostkonna album, 14-15.

50 Ibid., 13.

51 EAA.1921.217.1, 1-2.

52 Pärnumaa ap.-õigeusu praostkonna album, 15.
} 
sword, often the image includes a dragon that the saint has slain..$^{53}$ On many icons, Saint Georgy is represented protecting men against evil forces..$^{54}$ In the context of Russia and nineteenth century Livonia, it is important to note that Saint Georgy was the patron saint of Northern Russian Crusades while also being the patron saint of Novgorod ${ }^{55}$ and all Russia. ${ }^{56}$ So the choice of patronage for the Jõopre church iconostasis fits well into this narrative setting: on the one hand Saint Georgy related to Jüri Krauverk who was persecuted for his change of faith; on the other, Saint Georgy carried the word that suffering for one's faith can be a virtue and that justice would prevail; lastly and in common with Alexander Nevsky, Saint Georgy manifested unity of Russia and integrity of the Empire, thus being relevant for the Jõõpre church iconostasis both locally and on the state level.

\section{CONCLUSION}

Although many Orthodox churches built in Alexander II era Pärnu county are destroyed and in some cases we know little about their iconostases, on the basis of the current argument one can assert that not only location and architecture of the church, but also its interior and iconostasis involved significantly more far-ranging and profound messages than has been previously acknowledged.

It is clear that the subject is multi-layered and also that the appearance of Orthodox churches was shaped by innumerable influences, among which one of the more interesting issues was the rising national conscience of the Estonian peasant stratum, namely the way in which local population reacted to the encounter with the Orthodoxy and adopted it as its own. The Orthodox churches that were built in Pärnu county attest to the impact of the social, political and cultural settings as well as to the people and institutions involved in initiating or overseeing the work.

Although the study of architecture and especially icon painting is often considered a fenced field that is reserved only for art historians, one must grant that the multi-layered history embodied in the visual

\footnotetext{
53 Rosa Giorgi, Saints in Art (Los Angeles: J. Paul Getty Museum, 2003), 144.

54 Farmer, The Oxford Dictionary of Saints, 213-214.

55 Ibid., 181.

56 Enzyklopädie des Märchens: Handwörterbuch zur historischen und vergleichenden Erzählforschung, IV, ed. Kurt Ranke (Berlin: de Gruyter, 1987), 1032.
} 
subject matter of nineteenth century Orthodox churches also offers an interesting source of interdisciplinary research for social historians. It is a source that brings to us a mosaic of a complex and multi-layered world where self-determination and struggle for one's own place under the sun was in full stride.

Linda Lainvoo: Sociopolitical Messages in Eastern Orthodox Church Buildings of the Era of Alexander II in Pärnu County Keywords: Orthodox Church; Livonia, Russian Empire; conVERSION MOVEMENT

SUMMARY

In Estonian historiography, the topic of Orthodoxy and Orthodox churches has mostly been treated in connection to the Russian Empire and the Russification policy, rather than the local Estonian Orthodox Christians. Yet in the aftermath of the extensive religious conversions of the 1840s the number of Orthodox believers among Estonian peasantry in some regions rose to eighty percent or more of the population during the second half of the nineteenth century. Because of the active religious conversion, building of churches accelerated in Livonia during the 1860s and 1870s, covering some regions with an extensive network of Orthodox churches. This article surveys the Orthodox churches that were built in Pärnu county during the 1860s and 1870s, focussing on the iconostases of these churches, their iconographic setup, and sociopolitical significance.

The construction of Orthodox churches was a clearly conceptualised process that on the one hand served the interests of the local Orthodox converts but on the other, new churches functioned as landmarks that called attention to the presence of the Orthodoxy in the region. Exceptionally telling and important messages were also conveyed by the iconostases installed in these churches, as well as their iconic programs. Frequently, a central feature of the sociopolitical situation was the antagonism between manors and Lutheran congregations. Correspondingly, 
the iconostases of the Orthodox churches clearly reflect the prevailing situation in the congregation during the church construction, adding to the written sources a viable and attractive supporting source that facilitates the study of the period.

CV:

Linda Lainvoo has graduated from the University of Tartu with degrees in art history and theology. In 2011, she defended her master's thesis titled The Iconostases of the Orthodox Churches in Pärnu County in the 1860s and 1870s in the Institute of History at Tallinn University. Her main research field is Eastern Orthodoxy and Orthodox art in Estonia and Livonia during the $19^{\text {th }}$ century. Lainvoo works as a programme manager at the Kadriorg Art Museum (a subdivision of the Art Museum of Estonia). She has participated in the exhibition working teams at the Art Museum of Estonia as well as curated exhibitions. Since 2012, she is a lecturer in the Department of Art History at the University of Tartu. 
